\title{
Taxonomic status of genus Voousia Schoorl, 1990 (Lepidoptera: Cossidae: Zeuzerinae)
}

\section{Таксономический статус рода Voousia Schoorl, 1990 (Lepidoptera: Cossidae: Zeuzerinae)}

\author{
A.E. Naydenov ${ }^{1}$, R.V. Yakovlev ${ }^{1,2}$, F.C. Penco ${ }^{3}$ \\ А.Е. Найденов ${ }^{1}$ Р.В. Яковлев ${ }^{1,2}$, Ф.Ц. Пенко ${ }^{3}$
}

\footnotetext{
${ }^{1}$ Altai State University, pr. Lenina 61, Barnaul 656049, Russia. E-mail: colias24@mail.ru; yakovlev_asu@mail.ru

${ }^{1}$ Алтайский государственный университет, пр. Ленина 61, Барнаул 656049, Россия.

${ }^{2}$ Tomsk State University, Laboratory of Biodiversity and Ecology, Lenina pr. 36, 634050 Tomsk, Russia. E-mail: yakovlev_asu@mail.ru

${ }^{2}$ Томский государственный университет, Лаборатория биоразнообразия и экологии, пр. Ленина 33, Томск 634050, Россия.

${ }^{3}$ Fundación de Historia Natural "Félix de Azara", Departamento de Ciencias Naturales y Antropología, Universidad Maimónides, Hidalgo 775 piso 7 (1405BDB) Ciudad Autónoma de Buenos Aires, Argentina. E-mail: fernando_penco@hotmail.com
}

KEY WORDS: entomology, Lepidoptera, Carpenter moths, Zeuzerinae, fauna, Neotropical Region, Voosia, Brypoctia.

КЛЮЧЕВЫЕ СЛОВА: энтомология, Lepidoptera, древоточцы, Zeuzerinae, фауна, Неотропический регион, Voosia, Brypoctia.

ABSTRACT. The monotypic genus Voousia Schoorl, 1990, including Voousia punctifer (Hampson, 1898) from Lesser Antilles, is synonymized with the genus Brypoctia Schoorl, 1990. New combination is established: Brypoctia punctifer (Hampson, 1898), comb.n.

PЕЗЮМЕ. Монотипический род Voousia Schoorl, 1990, включающий Voousia punctifer (Hampson, 1898) с Антильских островов, синонимизирован с родом Brypoctia Schoorl, 1990. Установлена новая комбинация: Brypoctia punctifer (Hampson, 1898), comb.n.

\section{Introduction}

Cossidae (Lepidoptera) of Neotropic Region are studied fragmentary. In the recent years, a team of authors from Argentina, Germany and Russia achieved the first results in the detailed study of several Cossidae genera from South and Central America (primarily the subfamily Zeuzerinae) [Yakovlev, 2014; Penco et al., 2016, 2019a, b; Yakovlev et al., 2016, 2017, 2019a, b; Naydenov et al., 2019].

The genus Voousia was described by Schoorl, based on the structure of the appendages of the head and the thoracic sclerites [Schoorl, 1990], it included one species Voousia punctifer (Hampson, 1898) from Lesser Antilles. The genus Brypoctia Schoor, 1990 was also originally allocated by Schoorl for Xyleutes strigifer Dyar, 1910. Later, the taxon was re-described [Penco et al., 2016], and 5 new described species and 5 species of the genus Aramos Schoorl, 1990 were added to it as a result of its synonymization with Brypoctia [Yakovlev et al., 2019a].

In the course of the study of Voousia punctifer specimens we found that they are morphologically very close to representatives of the genus Brypoctia.

\section{Materials and methods}

Images of imago were taken by the camera of Canon EOS 70D and illuminated in Lightbox. The male genitalia slides were examined with a Zeiss Stemi 2000 C microscope and Olympus SZX16 microscope.The images were taken with the Olympus SZX16 camera. The genitalia and imago images were processed using Adobe Photoshop software.

Abbreviations used in the text:

MNHN - Museum National d'Histoire Naturelle, Paris, France

MWM - Museum of Thomas Witt, Munich, Germany

NHMUK - The Natural History Museum of United Kingdom, London, U.K.

USNM - United States National Museum of Natural History (Smithsonian Institution), Washington, USA

How to cite this article: Naydenov A.E., Yakovlev R.V., Penco F.C. 2020. Taxonomic status of genus Voousia Schoorl, 1990 (Lepidoptera: Cossidae: Zeuzerinae) // Russian Entomol. J. Vol.29. No.1. P.93-96. doi: 10.15298/ rusentj.29.1.13 


\section{Results}

In the study of external characters and genital structures of specimens of various genera of the subfamily Zeuzerinae Boisduval, [1828] from the New World Voousia punctifer (Hampson, 1898) proved to be very close to the species of the genus Brypoctia. The male genitalia have the following synapomorphies: laminar sprawls of the gnathos arms, the rodshaped process on the abdominal edge of the valve. Thus, there is no point in considering the genus Voousia as an independent, because no significant differences between genera were found, and respectively, the genus Brypoctia Schoorl, 1990 = Voousia Schoorl, 1990, syn.n.

Brypoctia Schoorl, 1990: 162

Type species (by monotypy): Xyleutes strigifer Dyar, 1910 (Figs 3, 7).

Brypoctia punctifer (Hampson, 1898), comb.n.

Figs 1-2, 5-6.

Duomitus punctifer Hampson, 1898, Trans. Entomol. Soc. London: 259-260.

TYPE LOCALITY. Grenada.

TYPE MATERIAL. Holotype, male in NHMUK, examined.

DISTRIBUTION. Lesser Antilles: Grenada, St. Vincent, St. Lucia, Martinique, Dominica, NEVIS.
MATERIAL EXAMINED. $1 \sigma^{\prime}$ (holotype), Grenada (NHMUK); $1 \mathrm{O}^{7}$, W. Indies, 24-247, Grenada (NHMUK); $1 \sigma^{7}$, Dominica, Leeward Is., Adams Bequest. B.M. 1912-399 (NHMUK); $1 \sigma^{7}$, W. Indies, 24-247, St. Vincent, W.I. H.H. Smith (NHMUK); $30^{77} \sigma^{7}$, Santa Lucia. 91-57. (NHMUK); 1 O7, Grenada (NHMUK); $1 \sigma^{7}$, Martinique, Colson, 24.IV.2001, J. \& Cl. Pierre (MNHN); 3 o $\sigma^{7}$, Martinique, Fond-Saint-Denis, 1-10.XI.2007, Cl. \& J. Pierre (MNHN); $10^{7}$, Martinique, les trois Ilets (Anse ã l'Ane), 17-1-1973, L. Matile Rec. (Lumiere) (MNHN); 1 , Antilles, Iles Leeward Nevis, VII-1981, J.P. Lecerf leg. (MNHN).

DESCRIPTION of male genitalia. Uncus of medium size, triangle, gradually narrowing from base, but with slightly concave sides apically. Gnathos arms robust, apically passing into strongly sclerotized plates with folded outer edges and an acute angle dorsally, distance between dorsal edges of gnathos arms greater than between their abdominal edges. Valve of medium size, costal edge sightly bent in upper half; in medium third of abdominal edge of valve thin and short poorly sclerotized rod-like process below which there is a small notch. Juxta robust, with two rod-like lateral processes directed dorsally. Saccus large, semicircle. Phallus thick, slightly bent, a little longer than valve. Vesica aperture in a complicated dorso-apical position, with long ribbon-like poorly sclerotized cornutus in vesica lateral surface.

TAXONOMIC NOTES. It is obvious that the genital structure of Brypoctia punctifer is very close to that of the other specimens of the genus. For example, in the species of $B$. strigifer (Dyar, 1910) (Distribution: Mexico, Costa-Rica, Honduras, Guatemala, Columbia) (Figs 3, 7) and B. ramosa (Schaus, 1892) (Distribution: Brasilia) (Figs 4, 8) the shape of the uncus, valves and gnathos arms etc., is practically identical.

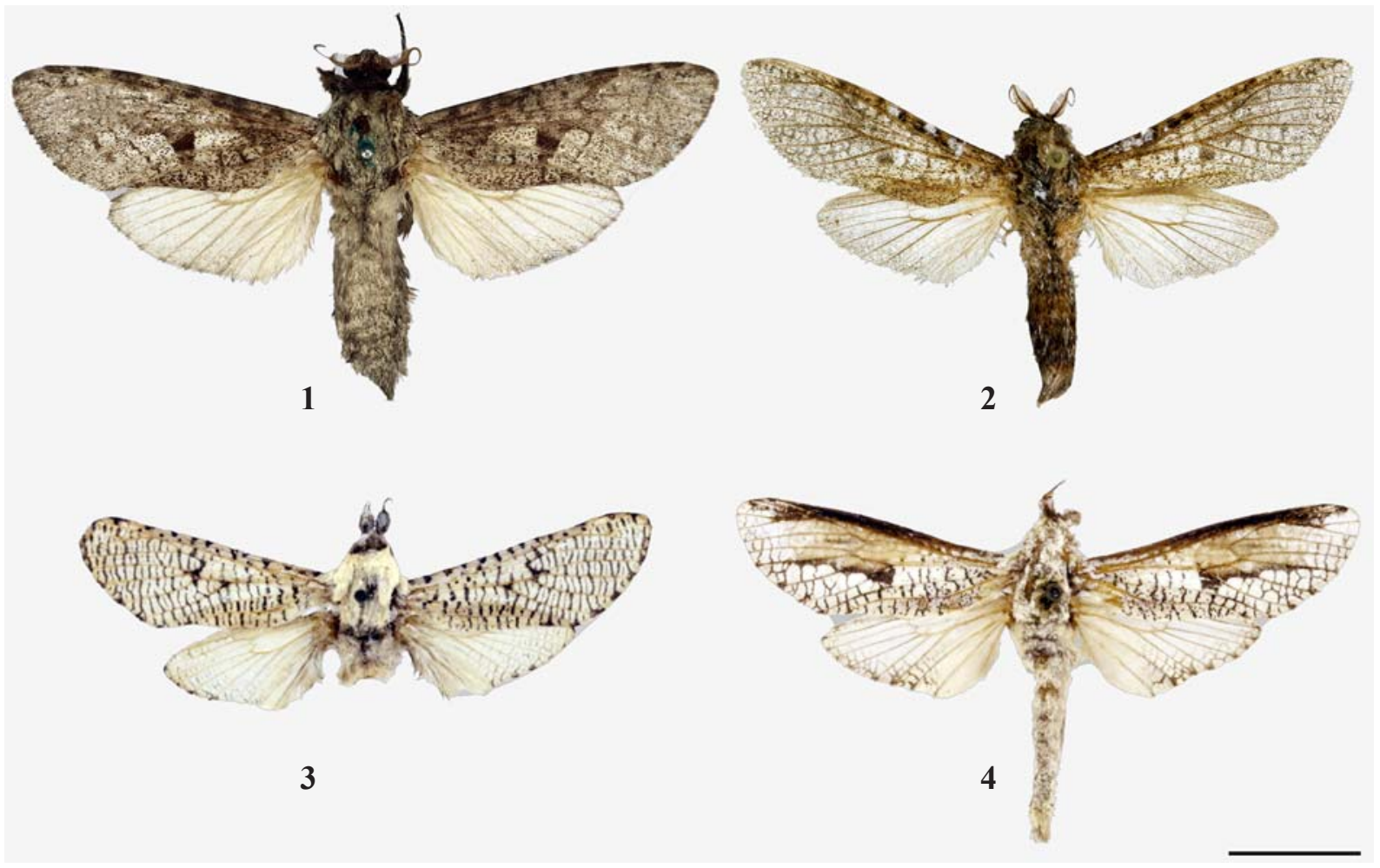

Figs 1-4. Brypoctia, adults: $1-$ B. punctifer, $\bigcirc^{\top}$, Grenada (NHMUK); $2-$ B. punctifer, $0^{\top}$, Martinique, Colson, 24.IV.2001, J. \& Cl. Pierre (MNHN); $3-$ B. strigifer, $\sigma^{2}$, holotype, Orizaba, Mex. (USNM); $4-B$. ramosa, $\sigma^{7}$, holotype, Rio Janeiro. (USNM).

Рис. 1-4. Brypoctia, имаго: 1. В. punctifer, О', Гренада (NHMUK); 2 - B. punctifer, О, Мартиника, Колсон, 24.IV.2001, J. \& Cl. Pierre (MNHN); 3 - B. strigifer, ơ, голотип, Оризаба, Мексика. (USNM); 4 - B. ramosa, o, голотип, Рио-де-Жанейро. (USNM). 
The most indicative external characters are: 1) antenna colour (thus, B. punctifer is closer to $B$. ramosa, having the same light brown antenna colour, unlike that black one in $B$. strigifer); 2 ) wings pattern (B. punctifer and $B$. ramosa have the same dark undulated pattern on light background on the fore wings, but with more darkness in the former; in B. punctifer the stroke in the medial and cubital-medial region is more pronounced; the hind wings in this species are less framed with undulated pattern than in B. ramosa and B. strigifer). Thus, Brypoctia punctifer is supposedly closest to Brypoctia ramosa and Brypoctia ramuscula.

Acknowledgement. Authors is grateful to Anna Ustjuzhanina (Tomsk) for the help in translation of the paper. The English text was reviewed by Prof. Boris Kondratieff (Fort Collins). The authors express their gratitude to Joël Minet

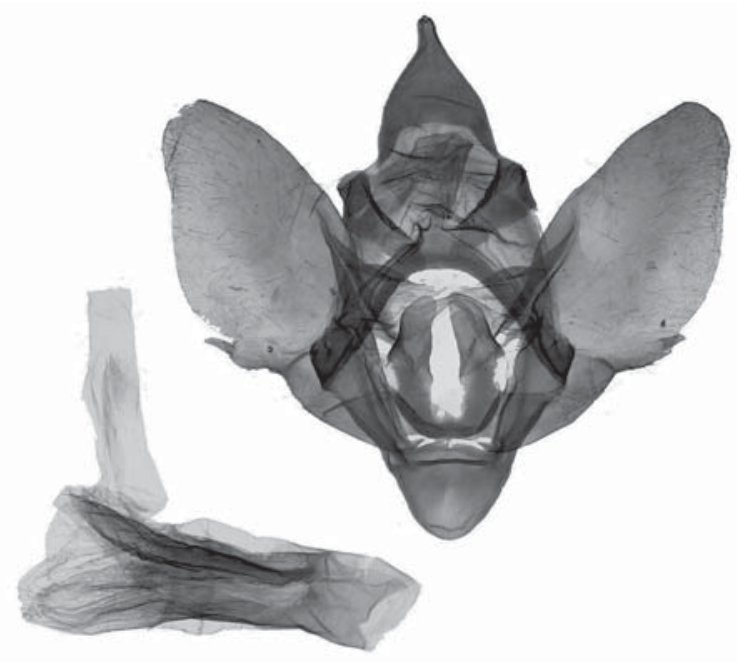

5

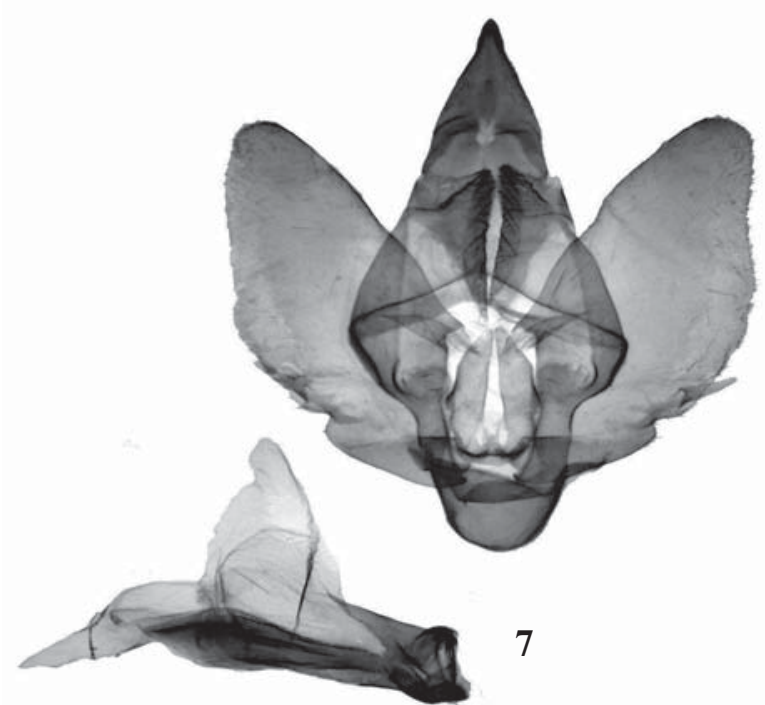

(MNHN) and Geoff Martin (NHMUK), to Harald SulakWildenauer (Munich) for providing the photos of the Cossidae type specimens from the USA museums. The authors are grateful to deceased Prof. Thomas J. Witt (Munich) for invaluable research assistance.

\section{References}

Naydenov A.E., Yakovlev R.V., Penco F.C., Witt Th.J. 2019. A new genus and species of the subfamily Zeuzerinae Boisduval, [1828] (Lepidoptera: Cossidae) from Brazil // Russian Entomological Journal. Vol.28. No.1. P.82-83. doi: 10.15298/rusentj.28.1.13

Penco F.P., Yakovlev R.V., Witt Th.J. 2016. Taxonomic Notes on the Genera Brypoctia Schoorl, 1990 and Schreiteriana Fletcher \& Nye, 1982 (Lepidoptera, Cossidae) // Zootaxa. Vol.4205. No.3. P.297-300. doi 10.11646/zootaxa.,4205.3.10

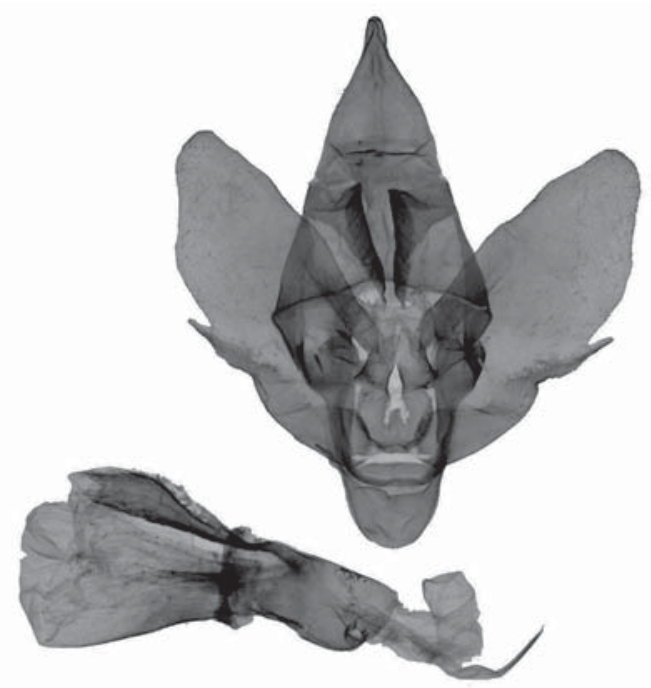

6

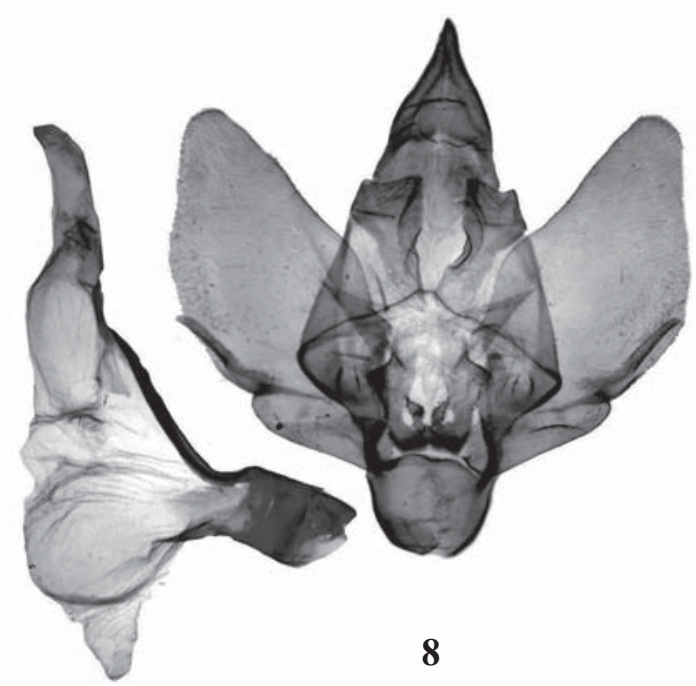

Figs 5-8. Brypoctia, male genitalia: $5-$ B. punctifer, Grenada (NHMUK); $6-$ B. punctifer, Martinique (MNHN); $7-$ B. strigifer, Mexico, Oaxaca Prov., Metates, $40 \mathrm{~km} \mathrm{~S}$ Valle national (GenPr Heterocera MWM: 28.541, MWM); 8 - B. ramosa, Brasil, Espirito Santo, Santa Teresa (GenPr Heterocera MWM: 28.548).

Рис. 5-8. Brypoctia, гениталии самцов: $5-$ B. punctifer, Гренада (NHMUK); $6-B$. punctifer, Мартиника (MNHN); $7-B$. strigifer, Мексика (GenPr Heterocera MWM: 28.541, MWM); 8 - B. ramosa, Бразилия (GenPr Heterocera MWM: 28.548). 
Penco F.C., Yakovlev R.V., Naydenov A.E. 2019. New species of genus Breyeriana Orfila, 1957 (Lepidoptera: Cossidae: Hypoptinae) from Argentina // Ecologica Montenegrina. Vol.20. P.114-118.

Penco F., Yakovlev R.V., Naydenov A.E., Witt Th. J. 2019. Two new species of the genus Givarbela Clench, 1957 (Lepidoptera: Cossidae: Hypoptinae) from South Neotropics // Zootaxa Vol.4577. No.3. P.596-600.

Schoorl J.W. 1990. A phylogenetic study on Cossidae (Lepidoptera: Ditrysia) based on external adult morphology // Zoologische Verhandelingen. Vol.263. P.1-295.

Yakovlev R.V. 2014. Redescription of the genus Miacora Dyar, 1905 from South America (Lepidoptera, Cossidae) // SHILAP Revista de lepidopterologia. Vol.42. No.165. P.57-60.

Yakovlev R.V., Penco F.C., Witt T.J. 2016. Redescription of genus Psychonoctua Grote, 1865 (Insecta: Lepidoptera,
Cossidae, Zeuzerinae) // Biological Bulletin of Bogdan Chmelnitskiy Melitopol State Pedagogical University. Vol.6. No.3. P.46-50.

Yakovlev R.V., Penco F.C., Witt T.J. 2017. Five new species of the genus Schreiteriana Fletcher et Nye, 1982 (Lepidoptera: Cossidae) from Peru and Columbia (South America) // Russian Entomological Journal. Vol.26. No.4. P.339-342.

Yakovlev R.V., Penco F. Witt T. 2019. Review of the Genus Brypoctia Schoorl, 1990 (Lepidoptera, Cossidae) with Descriptions of Five New Species from Central and South America // Entomological Review. Vol.99. No.3. P.407-415.

Yakovlev R. V., Sinev S.Yu., Naydenov A.E., Penco F.C., Witt Th.J. 2019. Redescription of the genus Allocryptobia Viette, 1951 (Lepidoptera: Cossidae) // SHILAP Revista de lepidopterologia. Vol.47. No.186. P.261-268. 